\title{
alphauille
}

\section{The ISEA 2011 Istanbul International Symposium on Electronic Art Sabaci Center, Istanbul, 14-21 September 2011}

A Conference Report by Jodi Nelson, University of Sussex

\section{Introduction}

Founded in the Netherlands in 1990, ISEA International (formerly Inter-Society for the Electronic Arts) is an international non-profit organisation fostering interdisciplinary academic discourse and exchange among culturally diverse organisations and individuals working with art, science and technology. The ISEA 2011 was held this year September 1421 at the Sanbanci Centre Towers in Levant, which is the financial and business district of the city. As the conference is now in its seventeenth year, the International Symposium on Electronic Art brought together over one hundred international artists from all over the world. With more than four hundred and fifty paper sessions, seventy panels, sixty workshops, as well as networking events, keynotes, exhibitions, performances, screenings and special events, the two-week conference certainly held something for everyone. Works of art and panel discussions covered from the gamut of algorithm art to robotics, from musical plants to art with bacteria. This year's conference aimed to explore the stories and achievements of the electronic arts by showcasing the endeavours of these artists and by catalysing local and international people, resources and interests.

\section{Seminar Series}

This year's event was held in many locations all over Istanbul, which provided not only access to a diversity of neighbourhoods, but also immersed the conference attendees in a feast of sights, sounds, smells and energies of everyday Istanbul. The organisers wanted the conference to resemble a travelling circus or a flash mob that appears and disappears, with each person bringing something, leaving something, and taking something home.

Indeed, this achievement was accomplished by inserting works of arts in neighbourhoods spread throughout the city, thus making the event an integral part of the heartbeat of the city itself. Taking place during the Istanbul Biennial, a city-wide festival of art and culture that recurs every two years, the conference intertwined with the cultural events of the city to not only showcase its massive endeavours to the attendees, but to immerse them in elements of authenticity they would take away with them to continue their artistic journey. According to writer Fiachra Gibbons of The Guardian, twenty years ago Istanbul was nowhere; now it stands up there with Venice and São Paulo among the art biennials that matter. If anything shows the rise of Istanbul as a cultural power, it is its arts biennial; and 
ISEA 2011 Istanbul wanted to be right in the heart of that cultural movement, as another act in the circus.

Overall, ISEA 2011 Istanbul was envisaged and developed with a focus on networking, generating new projects and developing new ideas, synergies, exhibitions and financial ties that will benefit the Istanbul art and technology scene and create international exchanges. The borders of contemporary national states present the observer with ideological and cultural frameworks that are no longer valid. Concepts of identity, nation state and belonging, as well as place and time are challenged in both real and virtual contexts. The Artistic Director, Lanfranco Aceti wanted to showcase the complexity of contemporary social interactions and the role that technology is playing in redefining contemporary aesthetics. "Uncontainable" was one of the main exhibitions, which provided a diverse perspective on the contemporary developments within fine arts aesthetics. That combined with other gallery exhibitions and installations, which were housed in the Museum of Contemporary Art Zagreb, the Kasa Gallery, the Sirket-i Hayriye Art Gallery, Cemberlitas Hamami and the Cumhuriyet Art Gallery/Maksem. A variety of themes included: "Dislocation", an art program of recontextualisations and transmediations of participation; "Southern Ocean Studies", a series of installation artworks that employ and comment on climate models of the Circumpolar Tide; and "Geometries of the Sublime", focusing on the world pioneers of contemporary geometric and digital arts - to mention just a few.

Screenings of "International Digital Media, Animation and Moving Images" and "Audiovisual Performances" also took place at the main conference headquarters at the Sabanci Center, as well as at the Sabanci University Performing Arts Center, which was a contributor to this year's conference. Singular events and practical workshops provided attendees opportunities to participate in various arts and technological debates and creative practices, such as: "Mapping as Walking as Learning to See in the Digital Age"; "Labster/Text Collecting Workshop"; and "Digital \& Media Reshaping Cultural Identity". Some of the workshops allowed attendees to build mobile apps, as well as create mindmapping strategies to the cultural significance of contextual art and technology convergence in specific areas of research.

Panels and paper sessions abounded and covered a wide range of topics such as, "Mobile Tagging for Augmented Reality"; "Architecture and the Experience of Digital Spatiality"; "Compumorphic Art: The Computer as Muse"; "Interdisciplinary Teaching and New Media Arts"; and "Code: Intellectual Property, Fair Use and Plagiarism". Far too many to attend even a third of these paper sessions, but I did manage to attend "Social Media and Digital Identities", where one of the presenters discussed how to extract meaning from data and how to filter memories. Another presenter debated the consumer excesses and attachment to things through the use of a creative blog post using pictures of items she bought, thus exploring themes of multipurpose, visibility and waste. In another panel, on "Digital Reality and the Perception of Self", a presenter explored ideas of how all the senses can inform global culture, which art is interpreted by humans, which is similar amongst ethnicity and culture.

\section{Reflecting on the Event}

As both an attendee and a speaker (on the panel: "The Experience of Film and Documentary") at this year's conference, I had conflicting opinions about the way in which 
the conference was executed and perceived by its participants. I was looking forward to seeing a much more professional group of speakers in the panel sessions, with far more experience and knowledge than I had about electronic media. I was also hoping for a more diverse ethnic group of participants as I expected a wider range of countries to present their own perspectives, for instance from Asia and Eastern Europe. The presentations I did get to see led to some disappointment on account of the lack of presentation skills and media training of some of the speakers, especially given the international perception of the conference itself.

However, the conference benefited greatly from the synergy with the Leonardo Electronic Almanac (Leonardo/ISAST-MIT Press) and with Goldsmiths College, University of London, which enabled the proceedings and publication program to reach an unprecedented international audience through e-platforms. The conference website was designed very well and was easy to navigate, and offered access to all the necessary information with regards the schedule, speakers, events, panels, workshops and arts installations associated with the conference.

The choice of packing such an overwhelming schedule into such a short time, however, was debatable; it was absolutely impossible to attend even fifty percent of the scheduled events. The scheduled offerings were held in various locations spread throughout the massive city, and sometimes there were up to five events going on at the same time. Even though it allowed the speakers to present and get published in the Leonardo Electronic Almanac, the conference fee of $€ 250$ was quite steep, especially when one was only able to make a few of the events. The attendee fee, however, was only $€ 18$ for anyone who wished to attend the full conference itself. Regrettably, there was no Facebook page, or any way to follow up with the speakers/presenters of those events missed to find out more about their research. In future, perhaps a less ambitious programme and a location such as a University Campus with all the proper facilities, including a gallery space, meeting rooms and places to eat and network, would be more ideal than the city-wide locations of this year's conference. While I understand the premise and the reasoning behind this monumental scheduling task, which certainly took an enormous amount of work to pull, I do not feel it benefited the attendee overall.

I will be interested to see what future projects come out of this year's engagement and look forward to visiting beautiful Istanbul again in the future. Overall, and in spite of some misgivings, my first experience of the ISEA conference was a positive one, as it was incredibly well organised and provided a truly international intellectual platform.

Jodi Nelson has been studying for a $\mathrm{PhD}$ in Critical and Creative Practice in Film/Media/Music at the University of Sussex since 2009. Her research interests fall primarily in how the new paradigm shifts in digital technology and the democratisation of the filmmaking process allow filmmakers to connect to a global niche audience with more immediacy then through the traditional sales and marketing channels. Specifically, through technology and social networking, she asks what means are available to reach a niche audience and how best to utilise this new participatory community/relationship to create art. 